\title{
Demographic Factors of Suicide in Chittagong
}

\author{
Kazal Kanti Barua ${ }^{1 *}$ \\ M. Jalal Uddin ${ }^{2}$ \\ Sumon Mutsuddy ${ }^{3}$ \\ AYM Masud Reza Khan ${ }^{4}$ \\ Ashim Barua ${ }^{1}$
}

${ }^{1}$ Department of Forensic Medicine Chattagram Maa-O-Shishu Hospital Medical College Chittagong, Bangladesh.

${ }^{2}$ Department of Community Medicine Chattagram Maa-O-Shishu Hospital Medical College Chittagong, Bangladesh.

${ }^{3}$ Department of Forensic Medicine Chittagong Medical College Chittagong, Bangladesh.

${ }^{4}$ Department of Forensic Medicine Chattagram International Medical College Chittagong, Bangladesh.

\section{*Correspondence to:}

\section{Dr. Kazal Kanti Barua}

Associate Professor

Department of Forensic Medicine

Chattagram Maa-O-Shishu Hospital Medical College

Chittagong, Bangladesh.

Mobile : +8801711117403

E-mail:drialal65@gmail.com

www.banglajol.info/index.php/CMOSHMCJ

\begin{abstract}
Background: Suicide is a devastating problem. It is to some extent preventable if we are aware of its factors. These factors vary according to community, cast and creed. Many studies were conducted at many places of the world but there is none in Chittagong. To know the high risk factors of suicide in Chittagong we have conducted the study. Methods : It was a descriptive study. Secondary data were used. All suicidal reports of Chittagong mortuary in 2012 were studied. Collected data were managed manually. Results were contrasted with recent studies of home \& abroad. Results: Total 165 reports were studied. Majority of the victims $128(78 \%)$ were of 15-45 years age group. Male female ratio was 49: 51 . Married victims were $109(66 \%)$. Muslims 125(76\%). Majority of the victims 104(63\%) were poorly literate $(<\mathrm{SSC})$. Commonest profession of the victims was 'housewife'57(35\%). Next professional group was lower subordinate staffs 49(30\%). Commonest method of suicide was Hanging 83(50\%). Family feud was the commonest cause of suicide and it was 72(44\%). Conclusion: Commonest demographic factor of suicide in Chittagong is 'Family Feud' It is mostly manageable and thus we can prevent suicide occurrence significantly. So, everybody should come forward to remove causes of family feud and others for a noble humanitarian cause.
\end{abstract}

Key words : Sucide; Hanging; Poisoning; Family feud.

\section{INTRODUCTION}

Suicide is the intentional termination of one's own life. It is mostly due to emotional blackmailing. Sometimes it is due to physical and mental disorders ${ }^{1}$.

According to WHO rate of suicide was 18/ Lac populations in 1995.Germany was the highest and Spain was the lowest suicidal rate at that time. The figures were 40 and 4 per Lac population respectively ${ }^{1}$. Suicide is comparatively less in Muslim countries. In Bangladesh it is 13/ Lac population. Jhenaidah district is the worst affected area $^{2}$.

Suicide is a heinous act. It is totally destructive to the victim and devastating for the family and friends. It is a great sin in all religions and suicidal attempt is a punishable offence in country law ${ }^{3}$. The problem is increasing day by day and it has become a public health problem worldwide but the problem is preventable up to great extent.

The aim and objective of present study is to detect prime factors responsible for suicide in Chittagong so that we can take effective measures to control the problem.

\section{MATERIALS AND METHODS}

It was a descriptive study. All suicide post mortem record sheets of 2012 (Secondary data ) were collected from Chittagong mortuary. It was 165. All sheets were meticulously studied. Collected data were managed manually. Results were compared and contrasted with recent studies of home and abroad. Finally a conclusion was drawn. 


\section{RESULTS}

Total recorded cases in 2012 were 165. Majority 128(78\%) were of 15-45 years age group. Female predominant 84(51\%).Married 108(65\%).Muslims 125(76\%). Majority $104(63 \%)$ of the victims were poorly educated (Class 0-X). Among the victims: Housewife 57 (35\%) Service holder $49(30 \%)$ and Day laborer 38(23\%). Hanging was the number 1 method of suicide. It was $83(50 \%)$. Next choice was poisoning $72(44 \%)$. Number one cause of suicide was Family Feud $72(44 \%)$. Suicide mostly occurred at night $107(65 \%)$ and suicide note was found in $133(81 \%)$ cases. There was no history of addiction in $119(72 \%)$ cases and no previous attempt in $148(90 \%)$ cases.

Table 1 : Demographic factors for suicide in Chittagong.

\begin{tabular}{|c|c|c|c|c|c|}
\hline \multirow{2}{*}{$\begin{array}{l}\text { Factors } \\
\text { Age group }\end{array}$} & \multicolumn{3}{|c|}{ High risk } & \multicolumn{2}{|c|}{ Low risk } \\
\hline & $15-45$ years & & $128(78 \%)$ & Others & $=37(22 \%)$ \\
\hline Sex & Female & & $84(51 \%)$ & Others & $=81(49 \%)$ \\
\hline Marital status & Married & - & $108(65 \%)$ & Others & $=57(35 \%)$ \\
\hline Religion & Non Muslim & - & $40(24 \%)$ & Muslim & $=125(76 \%)$ \\
\hline Education & Class 0-X & - & $104(63 \%)$ & SSC or More & $=61(37 \%)$ \\
\hline Occupation & Housewife & $=$ & $57(35 \%)$ & Others & $=108(65 \%)$ \\
\hline Place of suicide & Rural & & $86(52 \%)$ & Urban & $=79(48 \%)$ \\
\hline Time of suicide & Night & & $107(65 \%)$ & Day & $=58(35 \%)$ \\
\hline Suicide note & Found & & $133(81 \%)$ & Not found & $=32(19 \%)$ \\
\hline History of addiction & No & & $119(72 \%)$ & Yes & $=46(28 \%)$ \\
\hline Previous attempt & No & $=$ & $148(90 \%)$ & Yes & $=17(10 \%)$ \\
\hline
\end{tabular}

*High frequency is high risk. Non Muslim victims are more in comparison with their population

Table 2 : Methods of suicide.

\begin{tabular}{lr} 
Methods & Frequency \\
Hanging & $83(50 \%)$ \\
Poisoning & $72(44 \%)$ \\
Jump from height, under train, gun shot & $10(06 \%)$ \\
Total & $165(100 \%)$ \\
\hline
\end{tabular}

Table 3 : Causes of suicide.

\section{Causes}

Frequency

Family feud

$72(44 \%)$

Humiliated by guardian

$27(16 \%)$

Mental disorders

$24(15 \%)$

Love affairs

$14(08 \%)$

Sexual assault, social injustice, stigma

$28(17 \%)$

Total

$165(100 \%)$

\section{DISCUSSION}

Total recorded cases were 165 in 2012. This is similar to the observation by the weekly $2000^{3}$. According to the weekly 121 committed suicide within first 8 months of 2014. Actual figures may be a bit more because some cases may be missed somehow. However the frequency of suicide in Chittagong is around 2 per 1 lac population. It is supported by Wikipedia ${ }^{4}$. According to Wikipedia it is 2.06. Demographic factors (age, sex, education, occupation, religion, marital status etc) are similar to the study conducted by Ferozet $\mathrm{al}^{5}$. Poor, poorly educated and religiously back footed people commit suicide more than that of others and it is supported by recent studies ${ }^{4,5}$. Housewives are very vulnerable because they are poor, powerless and pregnant. Moreover they are provoked by social injustice to commit suicide. Our study shows housewives as number one occupational group to commit suicide and it is $57(35 \%)$. The finding is supported by other recent studies .According to Feroz et al $55 \%$ of committed or attempted suicide victims were housewives ${ }^{5}$. Demographic factors differ with that of developed countries. In developed countries older people commit suicide due to loneliness and different mental disorders ${ }^{7}$.

In our study number one method of suicide is hanging $83(50 \%)$. This is supported by all other studies in Bangladesh $5,6,7$. According to a report in the daily star hanging was $60 \%$ and according to Arafat common methods of suicide were hanging and poisoning ${ }^{6,7}$. Hanging materials are available and cost nothing. The second choice is poisoning and it is also supported by aforesaid studies . Others are: Jump from rooftop, Jump under train, Gun shot etc.

According to our study number 1 cause of suicide is family feud $72(44 \%)$. Second and fourth causes of suicide are also family related i.e humiliated by guardian and failed love affair. These figures are 27(16\%) and 14(08\%) respectively. Feroz et al described family discord $57 \%$. Figures are not significantly apart from one another. There are many facets of family disharmony. The prime causes are domestic violence, demand for dowry or any other gift item and poverty. Failed love affair, failed demand meeting and rebuke over study are common causes of suicide among the teen agers ${ }^{6}$.

\section{CONCLUSION}

Suicide destroys victim totally. It is an agony and stigma for relatives. Most of the factors for suicide are preventable as revealed in different studies. Awareness, alleviating poverty, social justice and religious uplift could drastically reduce suicide rate.

\section{DISCLOSURE}

All the authors declared no competing interest.

Source: Chittagong Mortuary 2012 


\section{REFERENCES}

1. Shaffer LB, Krug RS. Psychiatry. New Delhi. Jaypee Brothers. 1994.

2. Rahim AD. Mental Health. Dhaka: Asia publications. 2011

3. Azad SM. Suicide epidemic in Chittagong. Weekly 2014-5; 17(15): 14-15.

4. Arafat SMY. Suicide in Bangladesh context. Daily-sun.com 27 August 2016. Available from URL:https://en.wikipedia. org/wiki/suicide_in_ bangladesh.

5. Feroz et al. A community survey on the prevalence of suicidal attempts and deaths in a selected rural area of Bangladesh. Journal of Medicine. 2012.13(1): 3-9.

6. Khan T and Tasnin F. Suicide factfile, Bangladesh. The Daily Star 9th December,1:(Column 4-6) 2014.

7. Uzzal M. 28 people commit suicide everyday. Available at: http://archive.dhakatribune.com/crime/2014/sep/10/28-people-commit-suicide 